\title{
For A Really Open University
}

\author{
Patrick Ainley \\ School of Education
}

Lord Browne's Independent Review of Higher Education Funding and Student Finance, codified in the Government's White Paper, Higher education: students at the heart of the system, marks the end of efforts to reform society through education.

If carried into legislation, it will close a programme of progressive reform that began with the official introduction of comprehensive schools in 1965. These reforms paved the way for the expansion of further and higher education, including the polytechnic experiment. Unlike 11+ selection, which became a thing of the past in $80 \%$ of English secondary schools, reforming education at all levels was designed to change society by creating equal opportunities for all. The logic of reform carried forward to the inclusion of children with special needs, a common exam at 16 and a National Curriculum sold to school teachers as a universal entitlement, as well as - more recently - widening participation in higher education to nearly half of 18-30 year olds.

Now, arts and humanities study will be the preserve of overseas students and others rich enough to pay for it at elite and surviving campus universities. For the rest, increasingly vocationalised courses contracted out to the private sector will mean that only science, technology, engineering and medicine programmes will be state-funded as many of the remaining universities and colleges collapse and merge into local e-learning hubs offering part-time and distance learning provision.

We are therefore in danger of creating the social hierarchies witnessed in 1944-65, when social mobility only for a minority of 'bright' working class children was defined in narrowly academic terms. Only there has been no real social mobility since the 1970s when the post-war period of full male employment ended. It had allowed limited upward social mobility into the expanded non-manual middle class from the formerly industrial manual working class. Since then, there has only been apparent social mobility as widening participation presented itself as the professionalisation of the proletariat while disguising an actual proletarianisation of the professions, including particularly the academic and wider teaching profession. Now the false prospectus of professionalisation through education is becoming widely apparent as HE faces its own credibility crunch and many students are unlikely to mortgage their futures on raised fees for promised graduate premiums that cannot be redeemed.

$\mathrm{HE}$ therefore faces a future in common with schools and further education (FE). Education can no longer be complicit in sustaining false hopes for future generations. We have to recognise that the old nostrums - 'expand GDP and become better educated, trained and qualified' - no longer apply and we cannot educate our way out of recession. A new education is therefore necessary in relation to a sustainable and no-growth economy in which schools, colleges and universities will play a new part in regeneration an 
recreation of all sorts. This has been recognised by the more radical of the student resistance, informed not only with the tactics but the ideas of the climate camps and the alter-globalisation movement.

The sixth form and FE students who joined the November 2010 demonstrations knew their hopes for the future were being taken from them. Indeed, the strongest argument against raising fees, scrapping the Education Maintenance Allowance (EMA) and for returning to free post-compulsory education remains - what else are school leavers expected to do in "a youth labour market which has imploded", as Professor Alison Wolf says (three times!) in her March Review of Vocational Qualifications? 'Gringos' (graduates in non-graduate occupations) add a new tier of graduatised retailing to what is para-professional work at best, displacing non-graduates into even more part-time, precarious and deskilled jobs.

In a democratic society, education at all levels, as the institutionalised means of critically reproducing culture down the generations, aims to learn from the past to apply its lessons in the future. This is the purpose that public education at all levels must recover before it is too late. All courses of (higher) education should therefore aim not only at induction of students into disciplinary or cross-disciplinary areas of practice and their associated fields of knowledge, but also for students to add to these bodies of knowledge and their practical applications by new acts of creation, experimentation, investigation or scholarship as the warrant of the quality of their graduation. A public university, free and open to all applicants as an entitlement, requires such a new model of research and teaching. 